\title{
COMPARATIVE ANALYSIS OF THE EASTERN EUROPEAN COUNTRIES AS PARTICIPANTS OF THE NEW SILK ROAD
}

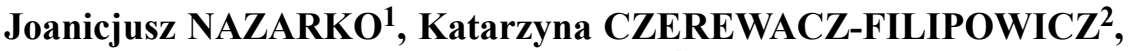 Katarzyna Anna KUŹMICZ ${ }^{3}$}

\author{
1,2,3 Faculty of Engineering Management, International China \\ and Central-Eastern European Institute of Logistics and Service Science, \\ Bialystok University of Technology, Wiejska 45A Street, 15-351 Bialystok, Poland

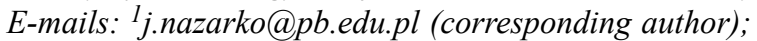 \\ ${ }^{2}$ k.czerewacz@pb.edu.pl; ${ }^{3}$ k.kuzmicz@pb.edu.pl
}

Received 14 December 2016; accepted 09 November 2017

\begin{abstract}
The Chinese One Belt One Road (OBOR) initiative often referred to as the New Silk Road (NSR), seems to be the greatest endeavour of our times in terms of economy, politics and logistics. The study aimed to examine the potential of Poland, Belarus, Lithuania, Latvia, Estonia and Russia to participate in the NSR. The method applied was comparative analysis including both quantitative and qualitative studies. The juxtaposition of data from the intensity of global integration enabled assessment of the potential negative consequences of non-participation of the countries in the NSR. In turn, the analysis of specific indicators of trade integration, the intensity of global integration and the logistics performance of the researched part of Europe has made it possible to answer the question about the most promising variants of the NSR.
\end{abstract}

Keywords: New Silk Road, One Belt One Road, global integration, trade exchange, transport corridor, rail transportation, logistics performance.

JEL Classification: R42, L91, L92, F15.

\section{Introduction}

The Chinese initiative of the One Belt One Road (OBOR), which is often referred to as the New Silk Road (NSR), is perceived as an opportunity to revitalise economies of the participating countries (Ejdys 2017). The momentum of the concept and the fact that at least 60 countries (Nazarko et al. 2016) are likely to participate in it necessitate a research of the NSR impact on some of the countries.

This study presents the research on the potential of Eastern Europe countries Poland, Lithuania, Latvia, Estonia, Belarus and Russia as participants in this undertaking. The focus is only on the land (rail) part of the NSR, considering the possible branching route in the Baltic part of Eastern Europe. Currently, there are several variants of the rail NSR (Shahbaz 2014) passing through the territories of some researched states but 
not the others. From the perspective of China, the multiplicity and diversity of new concepts of transport corridors with Europe are very beneficial because of a possibility to support most favourable options. The main research questions focus on the economic and logistics strategy of the countries in the frame of the NSR. Which is better for them: to compete or cooperate in building of the relations with China? Is it possible to create a common strategy among the researched EU and non-EU countries? Does the development of economic relations between China and the analysed countries allow for common strategy in the region?

From the perspective of Eastern Europe, the competition is not always beneficial. The elimination of one country from the NSR may have an adverse effect on its economy. In addition, the countries of Eastern Europe should be interested not only in obtaining the status of a transit country in the NSR but in the increase of international trade turnover, mainly exports.

The EU is the most important trade partner of China, while China is the second EU partner (European Union 2016). Eastern European countries that are EU members are not major trading partners of China lagging far behind Germany, Great Britain and the Netherlands (IMF 2016). The research presented in the paper focuses on identifying the researched countries that are most strongly trade-integrated with China.

The fact is that most of the countries that increase their trade with China mainly increase their imports but not exports. This results in a kind of trap and constitutes the reason behind the decision of the authors to investigate the way the export and import dynamics are shaped between the researched countries and China. The comparison of data from the intensity of global integration has enabled the authors to assess potential negative consequences of non-participation in the NSR from the perspective of the researched countries.

The analysis include: the changes of indicators of trade integration with China, the intensity of global integration, the logistical and infrastructural indicators, and selected aspects of the evolution of their economies. GDP and GDP per capita, as well as export and import levels, were mainly compared here to identify the developmental patterns of the countries under scrutiny (Gorynia 2016).

\section{Theoretical approach}

The facilitation of international transport, such as the development of transport infrastructure, the codification of rules, and the standardisation of solutions, translate into the development of the international trade of a country (Fujimura, Edmonds 2006). In turn, direct transport costs impede trade in a similar manner as tariffs. Suitable solutions for transport infrastructure and logistics are a crucial determinant of a country's ability to participate in the global economy. According to the research, it has been estimated that a 10 per cent increase in transport costs may reduce trade volumes of a country by more than 20 per cent (Limão, Venables 2001; Nordås, Piermartini 2004). Integration into the world economy is widely viewed as one of the key factors underlying the suc- 
cess of the fastest growing economies (The Growth Report 2008). Transportation costs are one of the most important factors that shape the directions, volume and the structure of trade (Behar, Venables 2011). On the other hand, the relationship between the level of trade and broader economic growth suggest a positive effect of increased trade and openness on economic growth (Frankel, Romer 1999).

There are numerous arguments for trade liberalisation (Balassa 1985). Free trade helps to avoid losses in management efficiency associated with protectionism (Krugman, Obsfeld 2009). Trade helps to overcome the limitations of small local markets (Bhagwati, Panagariya 1996) and makes it easy to access new technologies. However, in the case of the NSR, a multifaceted view beyond the issues of transport infrastructure and trade liberalisation is needed. Trade integration, as a result of the NSR, will cause the preferential effects for the participating countries and the discriminatory ones for those who find themselves excluded from this initiative (Marinov 2015). The discriminatory effects will be particularly felt by the countries, for which trade connections with the EU countries, China and other participants of the NSR are a priority. In their case, the trade diversion effect is going to be adverse. The researched countries can be found both in the group of beneficiaries, which will see the inflow of investments and the increase of their competitiveness etc. due to the NSR (El-Agraa 1999), and the group of the countries whose economies will suffer because of this initiative. Moreover, the geographical location of the studied countries means that many solutions concerning the NSR on their territories are in competition with each other or exclude each other.

Since China's new development paradigm is no longer based on an industrial output, cheap labour and exports but the development of internal consumption and services (Oziewicz 2015), this paper analyses the economy of the countries not only as consumers of the Chinese products but also business partners and suppliers of goods on the Chinese market. For this purpose, it was grounded on normative theory (Gorynia 2016) defining the directions of the evolution of economies of the countries and considering the role of exports in the GDP of these countries, including exports to China. Such a perspective seems to be important also because one of the biggest challenges in the economic relations of Central and Eastern European countries with China is their rapidly growing trade deficit in the turnover with the Member States and significantly higher growth of imports compared to exports to China (Li 2017).

\section{Trade integration between China and the selected EU Eastern European countries}

For the EU, China's share in the total trade turnover amounts to $13.8 \%$. Only the US has a larger share amounting to $15.3 \%$; however, considering the growth dynamics of trade with China, it is possible that it will overtake the United States in a few years. In turn, the European Union's share in the total turnover of China amounts to $14.3 \%$ making it the most important trading partner of the country.

Analysis of some separate Member States rather than the whole EU demonstrates that Poland takes the 31 st place among the countries to which China exports (the 8th place 
among the EU countries) and the 62nd place of the countries from which China imports (the 16th place among the EU countries) (IMF 2016).

The volume of the Polish foreign trade with China is growing steadily (bilateral trade turnover in 2008 amounted to 10473 million USD, and in 2015 to 16522 million USD). However, this is a consequence of the increase in imports rather than exports. From the bilateral perspective, a very high disproportion of the imports and exports causes the widening trade deficit of Poland (-12492 million USD in 2015). The volume of trade turnover between Lithuania and China is more than ten times smaller than that of Poland (919 million USD in 2015). For this reason, the position of Lithuania as a trading partner of China is distant. Among the countries from which China imports goods, Lithuania occupies the 122nd place (24th among the EU countries) and takes the 97th place in terms of China's exports (21st among the EU countries) (IMF 2016). Lithuania mainly imports from China. In the last four years, there has been some recovery in the exports of Lithuanian goods to China, while in terms of volume these were very small values (Lithuanian deficit with China in 2015 amounted to 692 million USD). Latvia is far below the top one hundred of the most important trade partners of China. In comparison with the EU Member States, its trade with China is among the smallest as well. However, unlike Poland and Lithuania, in recent years, due to the growth of Latvian exports to China, the deficit of Latvia's foreign trade turnover with China has decreased (-339 million USD in 2008 and -331 million USD in 2015). Estonia's position as a trading partner of China is close to the Lithuanian. Estonia is 111th among the most important countries exporting to China and 108th among the importers of the Chinese products. Among the EU countries, these are 23rd among the exporters and 24th among the importers. In 2009-2011, there was a rise of the Estonian imports from China, but it remained on a similar level for the next four years as well as exports and the trade balance (bilateral trade turnover in 2015 amounted to 844 million USD, and trade balance was -543 million USD).

The share of exports to China in the total Polish exports is around $1 \%$. This means that over the last six or seven years, none new product that would increase its presence in the Chinese market appeared in Poland. Meanwhile, China's share of the total Polish imports is increasing (Fig. 1). The imports from China have a lower price flexibility and profitability than from other countries. This is evidenced by the data from 2009 when the imports from China decreased in terms of volume, but its share rose because the reduction of the Polish imports was due to a decrease in the domestic demand. The percentage share of China as a trading partner of Lithuania never reached more than $1.5 \%$. The largest share of the total Lithuanian imports was reached by China in 2008 $(2.5 \%)$ and similarly at the end of the researched period. Meanwhile, the share of China as a direction of the Lithuanian exports steadily increased (Fig. 1). China's share in the Latvian volume of the trade turnover is growing steadily, but even in the record year 2015 it slightly exceeded $3 \%$ of the total imports and 1\% of the total exports (Fig. 1). In 2015, almost 5\% of the Estonian imports came from China, which was the largest share in the researched period. A little over 1\% of the Estonian exports went to the Chinese market. This means that the role of China among Estonia's trade partners is growing slowly but steadily (Fig. 1). 


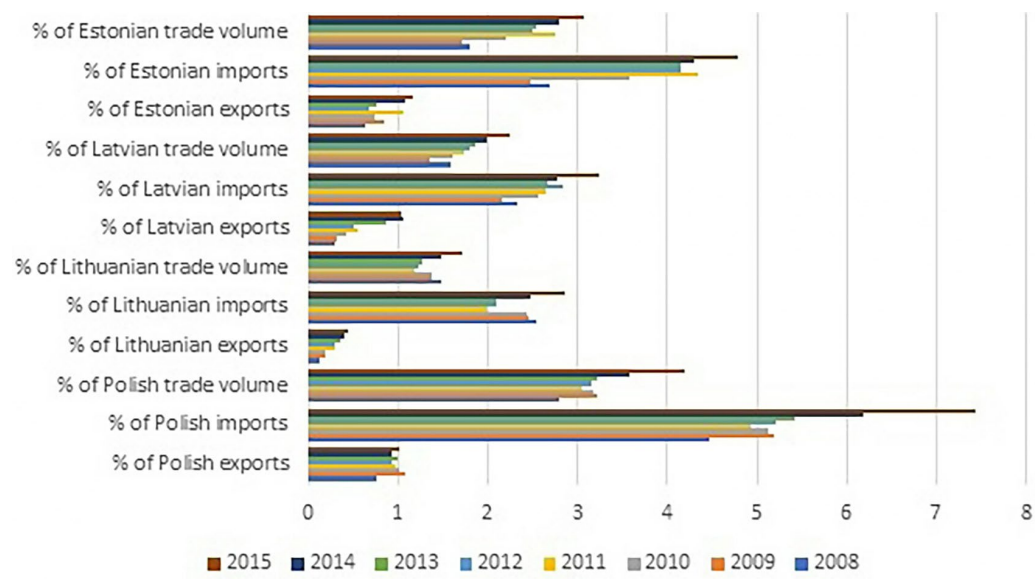

Fig. 1. China's share of the Polish, Lithuanian, Latvian and Estonian exports, imports and the trade volume

Source: own calculation based on IMF (2011, 2015, 2016).

\section{Trade integration between China and selected non-EU Eastern European countries}

The role of China as a trading partner of Belarus is growing steadily. Although the Belarusian trade is dominated by the relations with Russia, China is more clearly making its share significant, despite the geographical distance. This is mainly due to the growth of the Chinese investment and imports; however, in 2014-2015, the Belarusian exports to China increased as well and the trade deficit of Belarus in bilateral relations decreased (in 2013 deficit amounted to 2368 million USD and in 20151618 million USD). Russia's trade turnover with China is much higher than with other researched countries, which is the effect of Russia's policy, geographical location, owned resources and raw materials. Despite Russia's declarations that China could become its strategic partner and despite the growing role of China in the economic turnover of Russia, from the perspective of China, Russia is within the top ten of the most important trading partners. In 2010-2014, the volume of the mutual trade turnover between Russia and China grew steadily, both in exports and imports. In 2015, the bad condition of the Russian economy had a negative impact on the level of trade with China. The devaluation of the Ruble, low oil prices and impoverishment of the Russian society meant that the volume of mutual trade turnover decreased (bilateral volume of trade in 2014 amounted to 88426 million USD and in 2015 - 63552 million USD).

The imports from China in 2015 amounted to nearly $8 \%$ of the total Belarusian imports, and the exports to China grew almost to $3 \%$ of the total exports (Fig. 2). In the case of Russia, compared to other geographical directions, the decrease in the volume of trade with China was relatively lower than that with the Western countries. Therefore, in 2015, up to $16 \%$ of the Russian imports came from China, and over $11 \%$ of the Russian 
exports went to the Chinese market (Fig. 2). Among the researched countries, the Chinese imports from Russia were by far the largest. On the other hand, Poland definitely stands out among other countries due to dynamics of imports from Poland (Fig. 3). The Chinese exports to the Russian Federation showed a definite upward trend in the period 2010-2014. The year 2015 resulted in both a reduction in the volume of exports to Russia and Russia's role as an export direction. In the case of Poland, it is possible to talk about the permanent increase in the export volume, but with high dynamics of the total exports of China, as the percentage share of the country did not change during the researched period. For other countries, it is difficult to talk about a clear upward trend (Fig. 3).

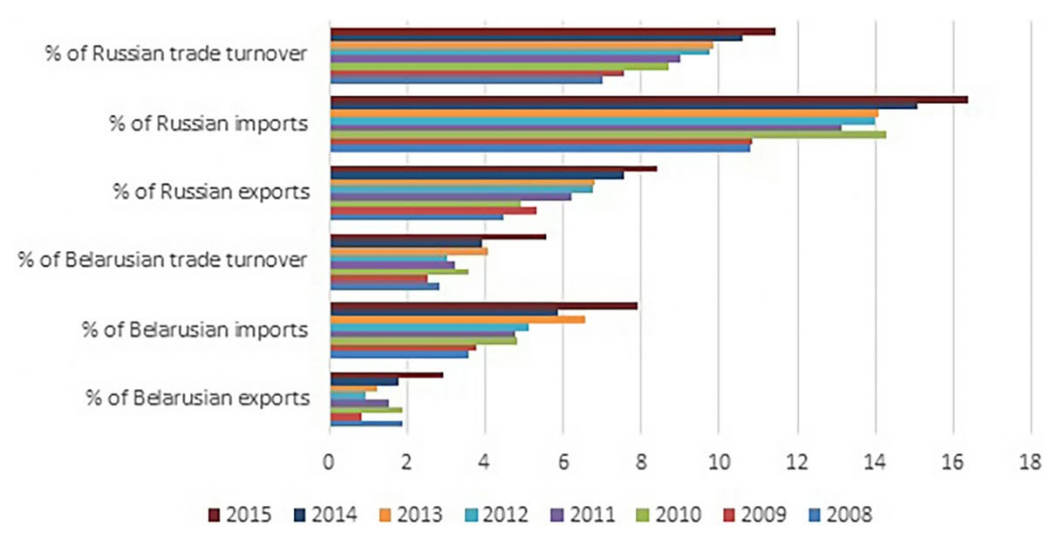

Fig. 2. China's share of the Belarusian and Russian exports, imports and the trade volume Source: own calculation based on IMF (2011, 2015, 2016).

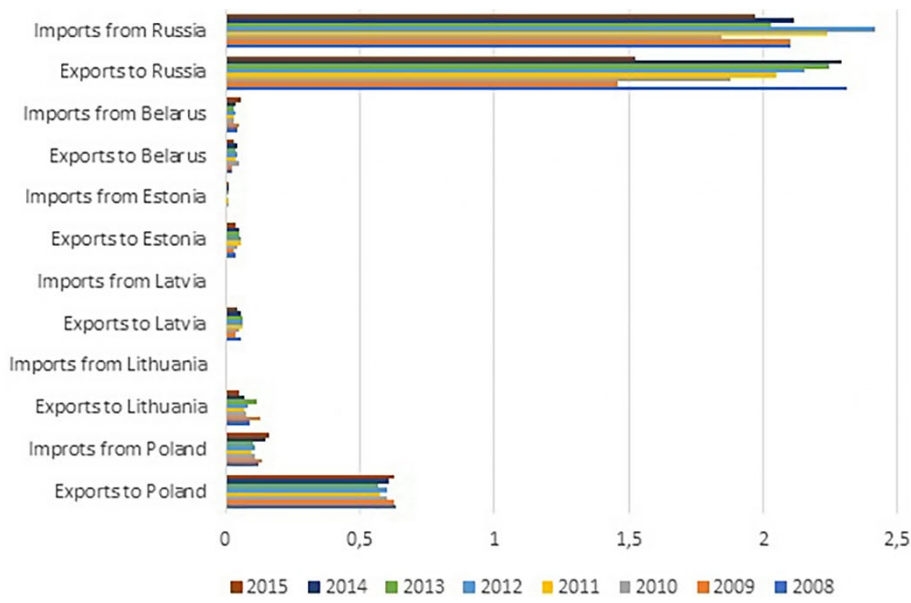

Fig. 3. Percentage share of the researched countries as a direction of the Chinese imports and exports

Source: own calculation based on IMF (2011, 2015, 2016). 
In percentage terms, the researched countries comprise about $2.5 \%$ of the Chinese imports. However, in the researched period, from Russia had between 1.8 and $2.4 \%$. In total, all the researched countries did not amount to an even $3 \%$ of the Chinese exports. Over the researched period, no clear upward trend in the case of any of them could be indicated.

\section{Analysis of the logistics performance of the selected Eastern European countries}

If the NSR concept is to be realised, participating countries need to face various challenges connected with the interoperability of the corridor (Nazarko, Kuzmicz 2017). Countries aspiring to be on the route differ a lot in terms of their preparation in the area of logistics. The World Bank defines the Logistics Performance Index (LPI) which includes six components (Arvis et al. 2016):

1. The efficiency of customs and border management clearance.

2 . The quality of trade and transport infrastructure.

3. The ease of arranging competitively priced shipments.

4. The competence and quality of logistics services.

5. The ability to track and trace consignments.

6 . The frequency with which shipments reach consignees within scheduled or expected delivery times.

These components can be grouped into the two main categories (Arvis et al. 2016):

- areas for policy regulation, indicating main inputs to the supply chain (customs, infrastructure, and services);

- supply chain performance outcomes (corresponding to LPI indicators of time and reliability: timeliness, international shipments, and tracking and tracing).

The logistics performance of the analysed countries was assessed via the survey conducted among logistics professionals from international freight forwarders and express carriers. The respondents were deliberately chosen because they directly affect the choice of shipping routes and gateways, thereby influencing the decisions of firms on production location, choice of suppliers, and selection of target markets.

From the perspective of the NSR initiative, the logistics performance of the participating countries is crucial. Presented below is the scheme of the indicators comprising LPI of the countries on the route (Fig. 4).

Despite a better evaluation of Ukraine in terms of almost all categories in comparison to Belarus, Ukraine is unlikely to play a significant role on the route because of the conflict with Russia. From among Poland, Ukraine, Belarus, Lithuania, Estonia, Latvia and Russia, the highest logistics performance indicator in 2016 belongs to Lithuania, Poland and Estonia (Fig. 5). Belarus has the lowest result. When analysing the specific components of the LPI in terms of policy regulations, the highest score from the assessment of customs clearance, infrastructure development, and the quality and competence of logistics unsurprisingly belongs to the EU countries. Russia and other former countries of the Soviet Union appear to be rather far behind their competitors. This does not 


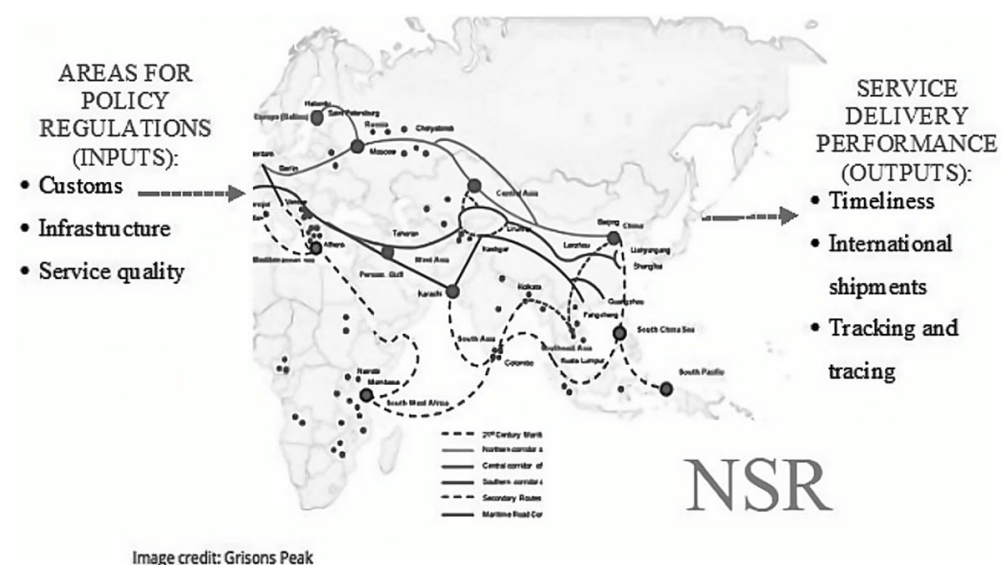

Fig. 4. Logistic performance index on the NSR

Source: authors elaboration based on the Arvis et al. (2016), graphs

(Massive Chinese lending 2015).

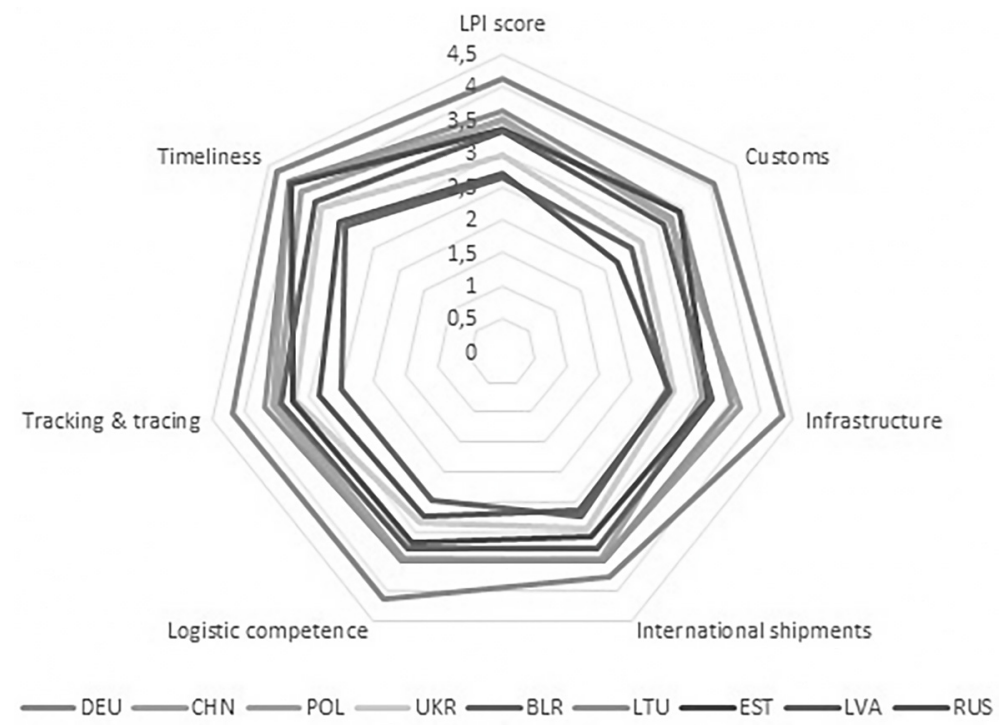

Fig. 5. LPI score and its components for the analysed countries, Germany and China, 2016 Source: own calculation based on the World Bank (2016).

apply to the three Baltic states Lithuania, Estonia and Latvia, which can be substantiated by their specificity even during the Soviet times.

Analysing the components of the LPI it is surprising that the respondents of the World Bank survey gave a high evaluation of the delivery timeliness. It is on a similar high level of all countries. Taking into consideration that one of the examples of the demand in China for European products is dairy products, it can be seen as an important factor. The level of the tracking and tracing system of the flow of goods is one of the key fac- 
tors in logistics performance assessment nowadays. It was highly scored despite Belarus and Russia. The high level of infrastructure development again can be associated with the membership in the EU. The non-EU countries perform significantly worse.

All the analysed countries have the challenge to reduce the gap with Germany, which performs much better than Eastern European countries and comprises a key element of the Belt. Germany has the leading position not only in terms of a better road and rail infrastructure but also in the area of logistics service quality and IT solutions for the safety of the shipments. The overall performance of China is on a similar level to the leading Eastern European countries. Since OBOR became an important issue in the Chinese government, Chinese cities made substantial efforts to establish rail connections with Europe and to become important hubs on the NSR. Two connections from hightech Chongqing and Chengdu rapidly grew into a 39 route network linking together dozens of cities in China and Europe (Shepard 2016). This locally supported development resulted in a competition between cities for cargo and attracted the attention of the central government, which consequently took more control over the developing network of the Eurasian trains. As a result, the China Railway Express brand was created to be associated with the NSR. A similar competition started in Europe, where on a national and local level efforts are made to attract investments and develop the rail infrastructure for the expected benefits from the economic boost triggered by the NSR. There is a tendency of the logistic performance of the Eastern European countries to grow in the years 2010-2016. Lithuania especially has made significant progress during that time, and Belarus and Russia seem to be lagging behind.

Poland, Lithuania, Estonia and Latvia perform on a somewhat similar level in terms of LPI. Consequently, from the perspective of logistics, they can be similarly assessed. Although Ukraine outperforms Belarus, it is unlikely to play a major role in the NSR in the forthcoming future due to political instability. Therefore, the Northern corridor of the NSR running through Belarus is most likely to prevail. Lithuania, Estonia and Latvia would participate in the NSR as complimentary routes. Kabashkin (2012), Bulis and Škapars (2014) stress that the Baltic countries (Estonia, Latvia, and Lithuania) should become a link between two major economic unions, i.e. the EU and the Customs Union of Russia, Kazakhstan and Belarus, in the framework of the trans-continental logistic chain. Due to its geographic location and logistics potential, Poland seems to be predestined to become a gate to Europe for China, leading to Germany and other Western countries.

\section{Evaluation of the potential of the researched countries as participants of the NSR}

The potential of the researched countries as participants in the NSR was assessed based on four types of indicators. Firstly, the analysis concerned the volume and dynamics of trade between individual countries with China and the trade intensity with China calculated as the share of exports to China in the GDP of each country. As the second group of indicators, logistics performance indexes were taken into consideration. Then, dynamically, it was shown how the intensity of global integration is calculated for each 
country as the share of exports in the GDP. The last group of included indicators were the GDP and the GDP per capita, the use of which allowed the identification of the developmental characteristics of the researched countries.

Poland has been increasing its trade turnover with China for several years. The dynamics of imports is definitely better than that of exports, and this is not just a result of an increase in the domestic demand (e.g. 2015). The Polish intensity of global integration is constantly growing, including the trade intensity with China (Table 1).

Table 1. Evaluation of the potential of Poland as a participant of the NSR ${ }^{1}$

\begin{tabular}{cccccccr}
\hline Year & $\begin{array}{c}\text { GDP per capita, } \\
\text { current prices, } \\
\text { US \$ }\end{array}$ & $\begin{array}{c}\text { GDP, current } \\
\text { prices, US \$ } \\
\text { (billions) }\end{array}$ & $\begin{array}{c}\text { Intensity } \\
\text { of global } \\
\text { integration }\end{array}$ & $\begin{array}{c}\text { Trade } \\
\text { intensity } \\
\text { with China }\end{array}$ & $\begin{array}{c}\text { \% of Polish } \\
\text { export }\end{array}$ & $\begin{array}{c}\text { \% of Polish } \\
\text { import }\end{array}$ & LPI \\
\hline 2010 & 12601.91 & 479.20 & 33.3384 & 0.3382 & 1.01 & 5.14 & 3.44 \\
\hline 2012 & 13157.81 & 500.84 & 36.3026 & 0.3402 & 0.94 & 5.20 & 3.43 \\
\hline 2014 & 14336.78 & 545.05 & 40.1599 & 0.3768 & 0.94 & 6.18 & 3.49 \\
\hline 2015 & 12552.29 & 477.06 & 41.7930 & 0.4223 & 1.01 & 7.43 & $3.49^{*}$ \\
\hline
\end{tabular}

Note: *2016.

Source: own calculation based on IMF (2011, 2015, 2016), World Bank (2016).

The lack of dynamics in the development of logistics performance, however, determined that from the leader among the researched countries it fell to the second place in 2015 . If this situation does not change, in the future, transport corridors leading through Lithuania or Latvia might be more attractive than those via Poland. On the other hand, if all the states in the region were to exhibit a great deal of logistics dynamics, this would enhance the competitiveness of the whole region by strengthening its position in the OBOR initiative.

Table 2. Evaluation of the potential of Lithuania as a participant of the NSR

\begin{tabular}{cccccccr}
\hline Year & $\begin{array}{c}\text { GDP per } \\
\text { capita, current } \\
\text { prices, US \$ }\end{array}$ & $\begin{array}{c}\text { GDP, } \\
\text { current } \\
\text { prices, US \$ } \\
\text { (billions) }\end{array}$ & $\begin{array}{c}\text { Intensity } \\
\text { of global } \\
\text { integration }\end{array}$ & $\begin{array}{c}\text { Trade } \\
\text { intensity } \\
\text { with } \\
\text { China }\end{array}$ & $\begin{array}{c}\% \\
\text { of Lithuanian } \\
\text { export }\end{array}$ & $\begin{array}{c}\text { \% of Lithuanian } \\
\text { import }\end{array}$ & LPI \\
\hline 2010 & 12010.68 & 37.2 & 55.7258 & 0.1075 & 0.19 & 2.43 & 3.13 \\
\hline 2012 & 14354.25 & 42.89 & 69.0837 & 0.2098 & 0.29 & 2.10 & 2.95 \\
\hline 2014 & 16594.61 & 48.66 & 66.5844 & 0.2671 & 0.39 & 2.47 & 3.18 \\
\hline 2015 & 14259.60 & 41.42 & 61.5644 & 0.2655 & 0.44 & 2.86 & $3.63^{*}$ \\
\hline
\end{tabular}

Note: ${ }^{*} 2016$.

Source: own calculation based on IMF (2011, 2015, 2016), World Bank (2016).

\footnotetext{
${ }^{1}$ In Tables 1-6, values of individual indicators: Intensity of global integration $<0-100>$; Trade intensity with China $<0-100>$.
} 
The degree of integration into the global economy of Lithuania is the largest among all the researched countries (Table 2). In addition, the dynamics of the country's logistics performance during the considered period was the highest, and in 2016, Lithuania was characterised by the highest LPI. The dynamics of the GDP per capita is also high, which translates into an increase in the domestic demand. All of this points to the high potential of Lithuania in the NSR, but it is a relatively small country, and the advantages it has at its disposal could be used in the situation of the dynamic development of at least a few countries in the region.

Latvia has systematically improved its trade links with China by increasing imports considerably faster than exports. But, it is a country whose relationship with the world economy is constantly intensifying and the LPI is constantly improving (Table 3).

Estonia has the highest GDP per capita among the researched countries, and its economy is strongly integrated into the world economy, making exports one of the most important components of the GDP (Table 4). The conclusions concerning the country's participation in the NSR are similar to those of Lithuania and Latvia.

While the level of the intensity of the global integration of Belarus is very high and in 2012 it exceeded 70, in this case, it does not mean a significant degree of economic integration into the world economy, but mainly the economic integration and dependence on the Russian market. Belarus is the country with the lowest GDP per capita and the weakest LPI (Table 5). However, the geographical location of the country, its relations with China and Russia, as well as the dynamic Chinese investment in the country facilitate the Belarussian participation in the NSR. Moreover, a significant improvement in the Belarusian logistics performance could potentially be beneficial to Poland, Lithuania, Latvia and Estonia, and become a driving factor for that part of the NSR.

The situation of Russia, as already mentioned, is different from the other analysed countries. It is affected by the size, geographic location, resources and international economic policy of Russia. As a result of the conflict with Ukraine and Russia's mutual embargo on the relations with the West, Russia's GDP and the GDP per capita have deteriorated significantly, but the trend should be assumed to be reversed soon, and the NSR might be one of the driving factors. The problem of Russia in the context of the NSR initiative is a weak LPI. Moreover, Russia, despite its important role in the exports of raw materials, is characterised by a constant intensity of global integration (Table 6), which may suggest that the extent to which the country is going to engage in the NSR will be highly dependent on non-economic factors.

In terms of the logistics performance, the countries that seem to be best prepared to participate in the NSR are Lithuania, Poland and Estonia. Lithuania and Estonia are also the countries with the highest levels of integration into the world economy. However, their degree of the relationship with the Chinese economy is small (Fig. 6). Besides, the researched countries (except for Russia) are small states, so from the point of view of China, they should be treated as a group of states. In this respect, the appropriateness of the $16+1$ initiative can be seen. In turn, Russia is most economically connected with China. The problem, however, is the low LPI (Fig. 6). In turn, Belarus, whose LPI is the lowest among the researched countries, shows the highest dynamics of relations with China, which could eventually have a positive impact on the LPI of the country. 
Table 3. Evaluation of the potential of Latvia as a participant of the NSR

\begin{tabular}{cccccccc}
\hline Year & $\begin{array}{c}\text { GDP per capita, } \\
\text { current prices, } \\
\text { US \$ }\end{array}$ & $\begin{array}{c}\text { GDP, current } \\
\text { prices, US \$ } \\
\text { (billions) }\end{array}$ & $\begin{array}{c}\text { Intensity } \\
\text { of global } \\
\text { integration }\end{array}$ & $\begin{array}{c}\text { Trade } \\
\text { intensity } \\
\text { with China }\end{array}$ & $\begin{array}{c}\% \\
\text { of Latvian } \\
\text { export }\end{array}$ & $\begin{array}{c}\% \\
\text { of Latvian } \\
\text { import }\end{array}$ & LPI \\
\hline 2010 & 11228.12 & 23.80 & 37.1848 & 0.1680 & 0.43 & 2.56 & 3.25 \\
\hline 2012 & 13762.16 & 28.14 & 45.0604 & 0.2132 & 0.50 & 2.83 & 2.78 \\
\hline 2014 & 15689.52 & 31.40 & 43.3121 & 0.4458 & 1.05 & 2.77 & 3.4 \\
\hline 2015 & 13614.47 & 27.04 & 42.6035 & 0.44378 & 1.04 & 3.25 & $3.33^{*}$ \\
\hline
\end{tabular}

Note: *2016.

Source: own calculation based on IMF (2011, 2015, 2016), World Bank (2016).

Table 4. Evaluation of the potential of Estonia as a participant of the NSR

\begin{tabular}{cccccccr}
\hline Year & $\begin{array}{c}\text { GDP per } \\
\text { capita, current } \\
\text { prices, US \$ }\end{array}$ & $\begin{array}{c}\text { GDP, current } \\
\text { prices, US \$ } \\
\text { (billions) }\end{array}$ & $\begin{array}{c}\text { Intensity } \\
\text { of global } \\
\text { integration }\end{array}$ & $\begin{array}{c}\text { Trade } \\
\text { intensity } \\
\text { with China }\end{array}$ & $\begin{array}{c}\% \\
\text { of Estonian } \\
\text { export }\end{array}$ & $\begin{array}{c}\% \\
\text { of Estonian } \\
\text { import }\end{array}$ & LPI \\
\hline 2010 & 14654.28 & 19.54 & 59.4166 & 0.4606 & 0.74 & 3.59 & 3.16 \\
\hline 2012 & 17398.38 & 23.06 & 69.7311 & 0.4770 & 0.68 & 4.14 & 2.86 \\
\hline 2014 & 19953.51 & 26.26 & 61.0815 & 0.6474 & 1.08 & 4.30 & 3.35 \\
\hline 2015 & 17111.3 & 22.47 & 57.3654 & 0.6676 & 1.17 & 4.78 & $3.36^{*}$ \\
\hline
\end{tabular}

Note: $* 2016$.

Source: own calculation based on IMF (2011, 2015, 2016), World Bank (2016).

Table 5. Evaluation of the potential of Belarus as a participant of the NSR

\begin{tabular}{cccccccc}
\hline Year & $\begin{array}{c}\text { GDP per capita, GDP, current } \\
\text { current prices, } \\
\text { US \$ }\end{array}$ & $\begin{array}{c}\text { Intensity } \\
\text { prices, US \$ } \\
\text { (billions) }\end{array}$ & $\begin{array}{c}\text { Trade } \\
\text { of global } \\
\text { integration }\end{array}$ & $\begin{array}{c}\% \\
\text { intensity } \\
\text { with } \\
\text { China }\end{array}$ & $\begin{array}{c}\% \\
\text { of } \\
\text { Belarusian } \\
\text { export }\end{array}$ & $\begin{array}{c}\% \\
\text { of } \\
\text { Belarusian } \\
\text { import }\end{array}$ & LPI \\
\hline 2010 & 6023.15 & 57.22 & 44.1804 & 0.8389 & 1.88 & 4.83 & - \\
\hline 2012 & 6938.07 & 65.67 & 70.1386 & 0.6548 & 0.94 & 5.11 & 2.61 \\
\hline 2014 & 8316.01 & 78.74 & 45.8217 & 0.8128 & 1.77 & 5.86 & 2.64 \\
\hline 2015 & 5941.24 & 56.33 & 47.3815 & 1.3847 & 2.93 & 7.92 & $2.64^{*}$ \\
\hline
\end{tabular}

Note: *2016.

Source: own calculation based on IMF (2011, 2015, 2016), World Bank (2016).

Table 6. Evaluation of the potential of Russia as a participant of the NSR

\begin{tabular}{cccccccc}
\hline Year & $\begin{array}{c}\text { GDP per } \\
\text { capita, current } \\
\text { prices, US \$ }\end{array}$ & $\begin{array}{c}\text { GDP, current } \\
\text { prices, US \$ } \\
\text { (billions) }\end{array}$ & $\begin{array}{c}\text { Intensity } \\
\text { of global } \\
\text { integration }\end{array}$ & $\begin{array}{c}\text { Trade } \\
\text { intensity } \\
\text { with China }\end{array}$ & $\begin{array}{c}\% \\
\text { of Russian } \\
\text { export }\end{array}$ & $\begin{array}{c}\% \\
\text { of Russian } \\
\text { import }\end{array}$ & LPI \\
\hline 2010 & 11445.13 & 1638.46 & 24.4388 & 1.2072 & 4.94 & 14.28 & 2.61 \\
\hline 2012 & 15145.38 & 2170.15 & 24.3036 & 1.6483 & 6.78 & 13.98 & 2.58 \\
\hline 2014 & 14338.00 & 2063.66 & 24.0601 & 1.8172 & 7.55 & 15.08 & 2.69 \\
\hline 2015 & 9521.08 & 1365.87 & 24.9182 & 2.0946 & 8.40 & 16.37 & $2.69^{*}$ \\
\hline
\end{tabular}

Note: $* 2016$.

Source: own calculation based on IMF (2011, 2015, 2016), World Bank (2016). 


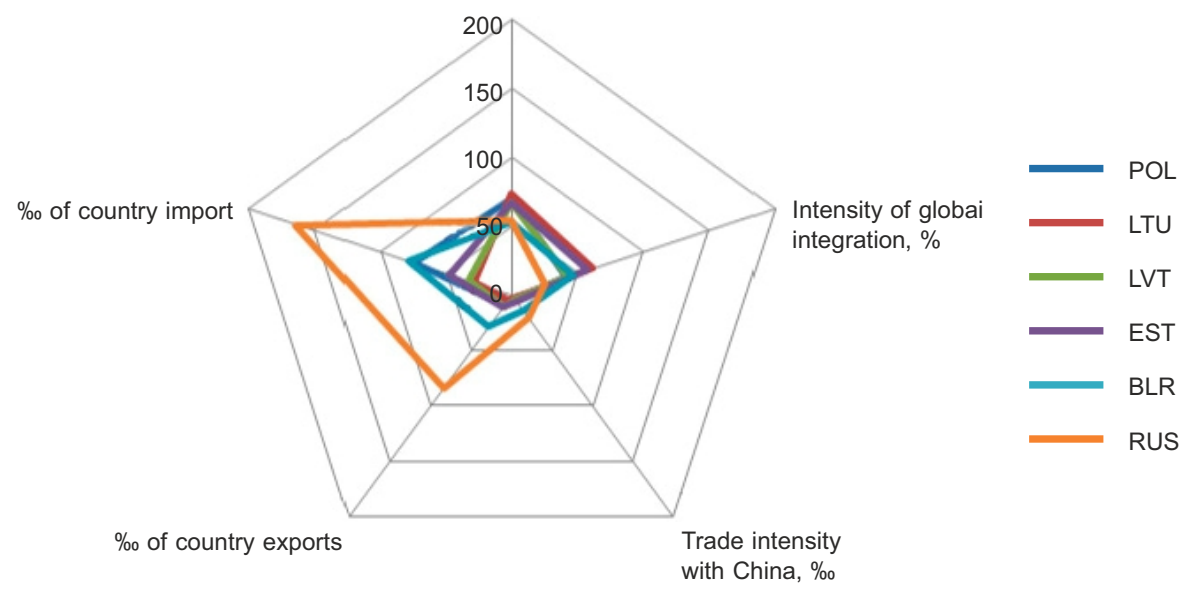

Fig. 6. Evaluation of the potential of researched countries as participants of the NSR Source: own calculation based on IMF (2011, 2015, 2016), World Bank (2016).

\section{Conclusions}

None of the researched countries is an important economic partner of China (Fig. 3) except for Russia. However, a clear upward trend in the trade with China is evident in the case of Poland and Belarus. In comparison with the EU countries, the role of the researched region, compared with Germany or Great Britain, is insignificant from the perspective of China. However, considering the geographical location of Poland and Belarus, upward trends in their relations with China, and the fact that the railway branch of the NSR supports specific types of goods, it seems that it will lead through Belarus and Poland.

If the studied countries want to play a considerable role in the NSR they have to improve their LPI to reduce their distance to the logistic performance of the Western European countries and be able to provide logistic services on the level ensuring smooth transportation of the goods through its territories.

The only reasonable strategy of the researched countries is cooperation. Competition could be dangerous because it could weaken the position of some countries. Otherwise, the Chinese economic power may deepen their trade deficits with China, and their role in the NSR could be limited only to transit. The outcomes of the research presented in Tables 1-6 prove that even a relatively high LPI and global integration index do not immediately mean high profits from the NSR. However, it should be taken into consideration that the presented research is limited by the novelty of the initiative and, hence, the lack of data. Therefore, a further analysis with consideration of other indicators is needed. Currently, it is difficult to find a good solution and a platform for cooperation between the researched EU countries, Belarus and Russia. Special consideration of work on a common strategy could be a direction of the future research.

The future studies could also involve an in-depth investigation of the impact of the specific groups of trade goods on the NSR development. Another interesting research field 
would be the bottlenecks influencing the NSR interoperability and effectiveness. Since most of the goods on the route China-Europe are transported in containers, it would be important to identify the bottlenecks in intermodal transportation on this route, including issues connected with limiting cost and time of container handling, container storage in depots on the route, empty container repositioning problems, congestions, the lucks or discontinuities of infrastructure especially in urban areas, and problems in information flow (Kuzmicz, Pesch 2017).

\section{Funding}

This work was supported by Bialystok University of Technology [MB/WZ/3/2016 and $\mathrm{S} / \mathrm{WZ} / 1 / 2014]$.

\section{Disclosure statement}

Authors declare that having no competing financial, professional, or personal interests.

\section{References}

Arvis, J. F.; Mustra, M. A.; Ojala, L.; Shepherd, B.; Saslavsky, D. 2016. Connecting to compete 2016. Trade logistics in the global economy. The logistics performance index and its indicator [online], [cited 20 January 2017]. The International Bank for Reconstruction and Development, Washington. Available from Internet: http://siteresources.worldbank.org/TRADE/Resources/2390701336654966193/LPI_2012_final.pdf

Balassa, B. 1985. Exports, policy choices, and economic growth in developing countries after the 1973 oil shock, Journal of Development Economics 18: 23-35.

https://doi.org/10.1016/0304-3878(85)90004-5

Behar, A.; Venables, A. J. 2011. Transport costs and international trade, in A. de Palma, R. Lindsey, E. Quinet, R. Vickerman (Eds.). Handbook of transport economics. Edward Elgar.

Bhagwati, J.; Panagariya, A. 1996. The economic of preferential trade agreements. Washington: AEI Press.

Bulis, A.; Škapars, R. 2013. Development of international freight transit in Latvia, Procedia Social and Behavioral Sciences 99: 57-64. https://doi.org/10.1016/j.sbspro.2013.10.471

El-Agraa, A. M. 1999. Regional integration. experience, theory, and measurement. New York: Palgrave Macmillan.

Ejdys, J. 2017. New silk road - a weak or a strong signal?, Procedia Engineering 182: 182-188. https://doi.org/10.1016/j.proeng.2017.03.159

European Union. Trade in goods with China. 2016. European Commission, Trade, Directorate General for Trade [online], [cited 5 July 2016]. Available from Internet: http://trade.ec.europa. eu/doclib/docs/2006/september/tradoc_113366.pdf

Frankel, J. A.; Romer, D. 1999. Does trade cause growth?, American Economic Review 89(3): 379-399. https://doi.org/10.1257/aer.89.3.379

Fujimura, M.; Edmonds, C. 2006. Impact of cross-border transport infrastructure on trade and investment in GMS. ADBI Discussion Paper no. 48. ADBI Tokyo.

Gorynia, M. 2016. Miejsce gospodarki polskiej w gospodarce Unii Europejskiej w latach 20032014 [The place of the Polish economy in the economy of the European Union in the years 2003-2014], Przeglad Zachodni [Western Review] no. 4. 
International Monetary Fund. Statistics Dept. 2011 Direction of Trade Statistics. Yearbook 2010. International Monetary Fund.

International Monetary Fund. Statistics Dept. 2015. Direction of Trade Statistics. Yearbook. 2014. International Monetary Fund.

International Monetary Fund. Statistics Dept. 2016. Direction of Trade Statistics. Yearbook 2016. International Monetary Fund.

Kabashkin, I. 2012. Freight transport logistics in the Baltic Sea region. Regional aspects, Transport and Telecommunication 13: 33-50. https://doi.org/10.2478/v10244-012-0004-X

Krugman, P.; Obsfeld, M. 2009. International economics. theory \& policy. $8^{\text {th }}$ ed. Boston: Pearson.

Kuzmicz, K.; Pesch, E. 2017. Prerequisites for the modelling of empty container supply chains, Engineering Management in Production and Services 9(3): 28-36.

https://doi.org/10.1515/emj-2017-0023

Li, J. 2017. The 16+1 mechanism and one belt one road initiative, new channels of promoting Sino-Czech relations, Global Economic Observer 5(1): 159-166.

Limão, N.; Venables, A. J. 2001. Infrastructure, geographical disadvantage, transport costs and trade, World Bank Economic Review 15: 451-479. https://doi.org/10.1093/wber/15.3.451

Marinov, E. 2015. Economic determinants of regional integration in developing counties, International Journal of Business and Management III(3): 22-39.

https://doi.org/10.20472/BM.2015.3.3.003

Massive Chinese lending directed to Silk Road 2015. China investment research [online], [cited 21 January 2017]. Available from Internet: http://www.chinainvestmentresearch.org/press/ massive-chinese-lending-directed-to-silk-road/

Nazarko, J.; Kuźmicz, K. A. 2017. Introduction to the STEEPVL analysis of the New Silk Road initiative, Procedia Engineering: 182: 497-503. https://doi.org/10.1016/j.proeng.2017.03.143

Nazarko, J.; Kuźmicz, K. A.; Czerewacz-Filipowicz, K. 2016. The New Silk Road - analysis of the potential of new Eurasian transport corridors, in Conference Proceedings The $9^{\text {th }}$ International Conference "Business and Management", 12-13 May 2016, Vilnius, Lithuania, 19-26.

Nordås, H. K.; Piermartini, R. 2004. Infrastructure and Trade. Staff Working Paper, World Trade Organization Report No ERSD-2004-04, Geneva [online], [cited 5 February 2017]. Available from Internet: https://www.wto.org/english/res_e/reser_e/ersd200404_e.htm

Oziewicz, E. 2015. Rola Chin we współczesnej globalnej gospodarce [The Role of China in the Contemporary Global Economy], Gdansk Studies of East Asia 2015/8.

Sahbaz, U. 2014. The modern Silk Road: one way or another?, On wider Europe. Black Sea Trust for Regional Cooperation.

Shepard, W. 2016. Why the China-Europe "Silk Road" rail network is growing fast, forbes [online], [cited 21 January 2017]. Available from Internet: https://www.forbes.com/sites/wadeshepa$\mathrm{rd} / 2016 / 01 / 28 /$ why-china-europe-silk-road-rail-transport-is-growing-fast/\#62aff8dc659a

The Growth Report: strategies for sustained growth and inclusive development. 2008. Commission on Growth and Development, World Bank, Washington, DC [online], [cited 5 July 2016]. Available from Internet: https://openknowledge.worldbank.org/bitstream/handle/10986/6507/449 860PUB0Box31010FFICIAL0USE0ONLY1.pdf?sequence=1\&isAllowed=y

World Economic Outlook Database. IMF. April 2017 [online], [cited 5 February 2017]. Available from Internet: https:/www.imf.org/external/pubs/ft/weo/2017/

World Bank data on Logistics Performance Index 2010-2016 [online], [cited 5 February 2017]. Available from Internet: http://lpi.worldbank.org/ 
Joanicjusz NAZARKO, PhD, DSc is a full professor of both technical and economic sciences, Ordinary Member of the Polish Academy of Engineering and a Presidium member of the Production Engineering Committee of the Polish Academy of Sciences. He was appointed to the Board of the Polish National Centre for Research and Development for the term of 2016-2020. He is currently serving as the Director of the International China and Central-Eastern Europe Institute of Logistics and Service Science at the Faculty of Engineering Management of Bialystok University of Technology. He also holds the posts of Professeur Associé at the Université du Québec à Trois-Rivières (Canada) and Honorary Professor of Zhejiang University Ningbo Institute of Technology (China). His academic interests include technology foresight, forecasting, modelling and simulation in technical and economic systems, logistic systems as well productivity analysis and benchmarking. He is the author or co-author of more than 200 technical and scholarly works published in reputable journals. He regularly speaks and presents his work at numerous Polish and international conferences. He has been a visiting professor at universities in China, Finland, Great Britain, Canada, Germany, Lithuania and USA.

Katarzyna CZEREWACZ-FÍLIPOWICZ, PhD is an assistant professor and Deputy Director for Organisation and Education in the International China and Central-Eastern Europe Institute of Logistics and Service Science in Bialystok University of Technology. She was a Visiting Researcher of the United Nations University Institute on Comparative Regional Integration Studies (UNU-CRIS), Bruges, Belgium and Warsaw School of Economics, Warsaw, Poland. She specializes in international economic processes of regional integration and international trade. She has written and edited a number of papers and monographs on international economic integration and international trade. The head of the research grant No.2011/03/B/HS4/05930 funded by the Polish National Science Centre on "Economic consequences of regional integration processes in the area of the Commonwealth of Independent States".

Katarzyna Anna KUŹMíCZ, PhD is an assistant professor and Deputy Director for Research and International Cooperation in the International China and Central-Easter Europe Institute of Logistics and Service Science at the Faculty of Management of Bialystok University of Technology (BUT) (a joint Institute with Zhejiang University Ningbo Institute of Technology (ZJUNIT) in China). She is a director of a cyclical summer school in logistics for ZJUNIT students at BUT and at ZJUNIT for BUT students. She has experience in national and international projects, she is an author of a number of research papers and an author of a monograph on process benchmarking. Her main scientific interests cover: international logistics, transport corridors, container transportation and benchmarking. 